\title{
ANDEAN DEITIES FROM ECUADOR: INDIGENOUS RITUALS AND TRADITIONS IN THE INTERCULTURAL CLASSROOM
}

\author{
Silvia-Maria Chireac, Anna Devis Arbona \\ Faculty of Teaching Training \\ University of Valencia, Spain
}

\begin{abstract}
The present study aims to analyse indigenous rituals and traditions of Ecuador, as well as other celebrations that nowadays are enjoyed by everyone in the Andean villages. The main goals are to describe the anthroponymy of Ecuadorian deities by explaining their original meaning and, at the same time, to analyse the impact of these traditions on Ecuadorian students from Spain. In the end, we propose some didactic considerations to help understand the importance of Andean deities and to carry out projects about indigenous rituals and traditions in a multilingual classroom, a context comprising students from different linguistic and cultural backgrounds.
\end{abstract}

Keywords: Ecuador, Andean deities, indigenous rituals, multilingual classroom.

\section{Introduction}

Linguistic contact between Castilian and indigenous languages dates back to colonial times, having surged in the first encounters of the Spanish with natives. Indigenous languages started being used for evangelization purposes and in public administration towards the 17th Century, as they became more and more common in the academic discourse of the first universities in America (Gómez Rendón 2008, Montemayor 2007). Linguistic contact occurs due to various factors: differences in the power balance and the degree of prestige each language holds, cultural differences (Chireac \& Francis 2016), the size of the indigenous population that lives in the country, the migration of speakers towards bigger cities, the importance of schools, churches and government institutions.

According to Article 1/2008 of its Constitution, the Republic of Ecuador manifests a singular treatment in the use of native languages within its borders, thus transforming the country into a multiethnic, multicultural and multilingual space that recognizes, protects and respects cultural diversity. The 2008 Constitution states that the official language of Ecuador is Spanish; in addition to that, Kichwa and Shuar are official languages employed in intercultural relations. There are 14 ancestral languages or native languages in Ecuador (see Figure 1); their use is official for the indigenous communities in the areas they inhabit: Achuar, Andoas, Awa, Chachi, Cofán, Epera, Huaorani, Kichwa, Secoya, Shiwiar, Shuar, Siona, Tsáchila and Zápara. The most 
widely spoken language in the entire Ecuadorian territory is Quichua (591,448 speakers, according to the National Statistics and Census Institute of Ecuador, 2010).

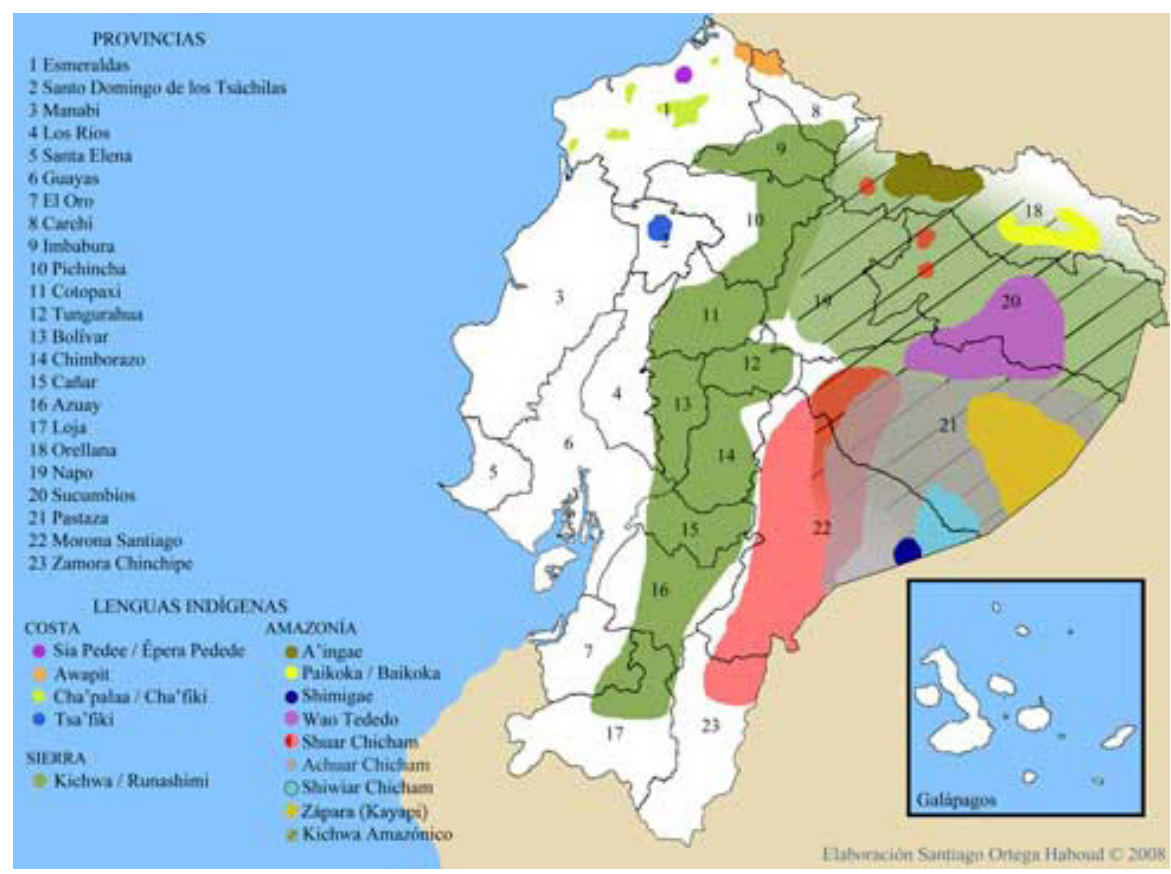

Figure 1. Provinces and native languages in Ecuador Source: Santiago Ortega Haboud (2008)

In the Quichua-speaking communities of Ecuador, Spanish is used for the main economic, political, educational and religious activities, since it is considered to be the language of prestige. Nonetheless, the use of native languages is still present, though limited to a more domestic area, in rural spaces and informal contexts: among relatives and friends, as well as in rituals. In their daily tasks, Ecuadorian indigenous people find a way to connect activities related to hunting, fishing, agriculture, etc. to deities that they still worship, even after the centuries that have passed since the conquest of the New World. Despite the Spanish colonisation and the evangelization process that of the indigenous people were subjected to, along with the exploitation they suffered at the hands of the conquerors, and despite the fact that their idols were destroyed, the Ecuadorian indigenous people keep celebrating their former gods every year. It got to the point where even Father Las Casas praised the indigenous people for their sense of religiosity and defended their rights, condemning the oppression carried out by the conquerors who prohibited the natives' idolatry, defaced their temples and vanquished their cultures.

The current article proposes a panoramic view of the main indigenous feasts and traditions that have been preserved to this day and are still celebrated in Ecuadorian 
villages. The objective is to describe the anthroponymy of Ecuadorian deities, their original meaning and, at the same time, to analyse the significance of such traditions and their impact on the Ecuadorian pupils enrolled in the Spanish educational system.

\section{Ancient Andean feasts}

Indigenous communities are the preservers of ancestral knowledge and cultural values. In the Andean world, life and its passage is not perceived in a linear manner, as it happens in the western version, but in a circular way, being composed of four great feasts, each of them related to the solstice, equinox and nature's cycles.

Ancient cultures discovered that all knowledge comes from studying the cosmos and its elements, including humans. In other words, nature and the human body are sources of knowledge for a great number of arts and sciences. There are several ancient feasts that are celebrated in Ecuador, but the most important ones are the four Raymikunas or ritual feasts that are being held during the summer and winter solstice and equinox. These are: Pawkar Raymi - Feast honouring Pachamama (Mother Earth), Inti Raymi - Feast of the Sun, Cápac Raymi - Annual festival or Festival of the Princes and Coya Raymi - Feast of the Queen and of the Moon (see Table 1). Each feast is related to the Andean agricultural cycle and its protagonist is corn. In Quichua, Raymi means 'ceremony, solemn feast'.

Table 1. Ancient feasts honouring Mother Earth (source: personal research)

\begin{tabular}{|l|l|l|l|}
\hline Ancient feast & Season & Date & Honouring \\
\hline $\begin{array}{l}\text { Pawkar Raymi } \\
\text { Sisa Paccha } \\
\text { TumariPukllay }\end{array}$ & Spring equinox & March 21 & Mother Earth, nature's flourish \\
\hline Inti Raymi & Summer solstice & June 22 & The Sun, the harvest, Mother Earth \\
\hline Coya Raymi & Autumn equinox & September 22 & The Moon, Mother Earth \\
\hline Cápac Raymi & Winter solstice & December 22 & Mother Earth's fertility \\
\hline
\end{tabular}

\section{Pawkar Raymi}

Pawkar Raymi is celebrated on the 21 of March, when the first food sources (mainly grains) appear. Given its Andean roots, it is one of the four festivities celebrated in Ecuador, Bolivia, Peru and other Latin American countries. In other Andean Ecuadorian villages, this feast is known as Sisa Paccha ('flourishing time') or Tumari Pukllay ('ceremonial game of water and flowers'). Native villagers celebrate this feast (the beginning of the Andean year) from January to March; they consider it a time of gratitude and interconnection of three worlds called Jananpacha ('the world above, the sky's geography'), Kaypacha ('Middle Earth, where we are') and Ukupacha ('the depths of the Earth, the world below'). To natives, this feast is an opportunity to give thanks to Pachamama for all they have received and for the products they enjoy. Pachamama (Mother Earth) or Mama Pacha is the deity representation of womanhood, a totemic Inca god (represented by the planet Earth) that receives offerings from its followers. 
The offerings are given to her in agricultural and livestock ceremonies that are still being celebrated in the Andean world. Pachamama is a Quichua word composed of two terms: pacha, meaning 'space and time, abundance, totality', and mama, representing the mother, the originator and conceiver of life and fertility. Pachamama is the wife of Tata Inti (Father Sun), protector and nurturer, who bestows fertility and favours fecundity, with whom followers are in constant contact and dialogue, since he is present in nature and in everything that surrounds humankind.

According to Andean cosmovision, Pachamama is in everything, everywhere (space/time), which results in a holistic view, since in the man-world everything that acts upon one of its elements necessarily affects the rest. It is a communal, solitary world, exempt from any sort of exclusion. Everyone/everything (man, tree or stone) is as important as anyone/anything else. A feeling of belonging characterises the communal world; you always know that you are a member of the community and you feel strongly connected to and committed with it.

In the Andean world everything is alive: not only humans, animals and plants, but also rocks, rivers, mountains and everything else. They all take part in the great celebration of life: they all eat, sleep, dance, sing; they all enjoy life's abundance. There is no world as a whole, separated in its integrity from the sum of its different components. There is a sort of symbiosis, which is closest to life in the Andes, experienced in a mutual manner.

Pawkar Raymi, the celebration honouring Pachamama, is connected to the main elements of life: water and flowers. Water is one of the vital elements for human life, not only for the native communities, but for the entire world. This celebration is when Pawkar Raymi's most important ancient ceremony, the Tumarina Pukllay, is performed. Women collect flowers and water from other streams, sources of healing and positive energy; these ancient elements are also used in a child's first bath, in marriages and in the last bath of the deceased.

The feast begins at four in the morning with the traditional cold bath. At eleven, when the sun is in the middle of the sky, the leading role is given to another person (by handing over the "responsibility cane"), in order for them to perform next year's celebration. Afterwards, the people walk to the centre of the parish where they have a communal meal and dance to Andean rhythms. The natives craft a chakana or chaka hanan, a Quichua term signifying 'stair' or 'high bridge'. They decorate the chacana (cross-like shape) with fruit, soft grains and flowers. Chakana is also the name of the Southern Cross constellation, a synthesis of Andean cosmovision and an astronomical concept related to the four seasons of the year. Towards the end of the ceremony, participants are offered pinzhi, a communal meal made of potato, buns, cheese, mote (corn variety), and chicha (alcoholic drink made by fermenting corn). The celebration ends when the participants return to the community in pilgrimage (Martín-Gutiérrez et al. 2016). 


\section{Inti Raymi}

Inti Raymi, Quichua for 'Feast of the Sun', is an ancient Andean religious ceremony honouring Inti (Father Sun) and Mother Earth and giving thanks for bountiful crops. It is also an opportunity to ask for the beginning of a prosperous new cycle. The offerings link the body, the fields and the Sun and provide a prosperous harvest until the following solstice. Inti Raymi represents the rebirth of the god, which is meant to bring about the beginning of a new yearly cycle. Incas believed that they had been sent to the Earth by their Father, the Sun. The feast was formerly celebrated by dancing, worshipping the ancestors, drinking, sacrifices and other ceremonies which lasted for 15 days (Eeckhout 2004). Nowadays, the celebration begins before the 17th of June and concludes on the 24th of June, in the morning, which is when the summer solstice occurs. The participants dance all day long around the tree of life, where they place fruit and flowers, along with their prayers. It is considered to be one of the strongest prayers for the communal good (Martín Gutiérrez et al.2016) and a dance that you have to perform with prior fasting. The people who take part in the dance devise 52 prayers in the form of yellow strips of fabric which symbolize the 52 nations of the world, according to their cosmology. The prayers are tied in a circular manner to the tree around which they are going to dance. To initiate the dancing ritual, the participants must undergo a purification process by entering a temazcal or 'vapour house', which represents the womb of the mother, where we go in order to be born again and to be reminded of who we are. The dancing ceremony consists of four "gates" or time intervals that represent the four sacred cardinal points: north, south, east and west. Upon finishing each gate, the dancers may rest and consume beverages, sacred medicines of their ancestors, such as aguacolla - the sacred cactus that opens the gates of heaven, or they can inhale the rapé (snuff, a powdered form of tobacco). Once the four gates are done, the ceremony ends with a temazcal that concludes the celebrations. Every participant gets an opportunity to strengthen their goals in life and reaffirm their connection to the Great Spirit.

Beyond the festive purpose of this celebration and that of expressing gratitude towards Mother Earth for all of the bountiful crops in Shuracpamba, the ceremony is also related to war rituals. Inti Raymi is thought to be the creator of fierce women and men, prepared to go into battle and wage war against all odds.

Thus, Inti Raymy is a religious and spiritual celebration that represents the replenishment of vital energies in people, with a rich symbology as to the instruments employed. It symbolizes the Earth's movements, rotation and revolution.

\section{Coya Raymi}

The feast known as Killa Raymi, Kuya Raymi or Coya Raymi (Quichua Quya Raymi Killa 'The Moon Feast') is celebrated in the Andean territory on the 22nd of September, during the autumn equinox. It involves fasting, singing and dancing rituals honouring the Moon Goddess (also known as qoya), sister and wife of the Sun. This goddess is the symbol of fertility and Pachamama. Coya was the legitimate wife of the 
Inca emperor and was also called Pihuihuarni ('wife') and Mamanhuarni ('mother'). She was also referred to as Hija de la Luna ('Daughter of the Moon').

It is a native feast in honour of the moon, the symbol of femininity (the Quichua term for moon is killa). Its roots go back to El Koya, a common Inca practice that consisted of selecting the best girls in the community and taking them to a mountain as an offering to Inti (Father Sun). The festivity was held in honour of the Queen, wife of the Inca, and in honour of the Moon, which was thought to be the mother of the Queen. Its aim was to preserve the health of the population.

Killa Raymi is a time of fertility and is related to women, symbolizing vitality and fecundity. This celebration is performed as an expression of gratitude to the Earth, women and fertility. Killa Raymi represents fertility; thus, the celebration is the perfect time to produce good offspring. For the women who take part in this native feast, one of the main objectives is to revitalize the sacred femininity and to foster peace and harmony in all hearts. To revitalize femininity means that woman needs to reconnect to Mother Earth and the Moon, expressing gratitude to them for her period, for being a life-giver, a Life that is given back to the mother. Coya Raymi Killa is also the month of the cleansing and removal of all sickness. To this end, the indigenous people perform rituals around the time Coya Raymi is celebrated, because it is the time of the year when rain abounds and people tend to become sick.

Nowadays, the feast stands for salvaging the cultural values and roots of the indigenous people, and is viewed as a reintegration process among other nationalities. For this occasion, the natives devise a symbol of fertility: a crescent moon chakana, decorated with fruit and flowers and filled with corn seeds, beans, sweets of sambo or pumpkin. The participants form a circle, raise their arms and facing north, south, east and west, and they perform the ceremony of Killa Raymi, the fertility ritual for the month of September. The ritual is accompanied by music and dancing.

\section{Cápac Raymi}

Cápac Raymi is the name of an Annual festival (also named Festival of the Princes) celebrated in the Andean villages on the 21st of December as a great feast of blossoming in preparation for the New Year. Due to the Spanish conquest and the imposition of the Catholic faith, it has been replaced by the celebration of Christmas. Nowadays, it is being rescued in some Andean communities, as a part of the cultural identity of the natives. It is celebrated once the corn harvest is concluded, as the final feast of the year.

The word kapak comes from the Peruvian Quechua and it means 'wise.' In Ecuador the term for someone who is a thinker, a wise man, a guide is Yuyac. December is the time of the year when it is customary to give children gifts, but it is especially important to ask the elder members of the family for their blessing for the coming year. This is also a time for celebrating leadership in its feminine and masculine components, given that the feminine time of the solar year is augmenting in intensity. All of this occurs in a gender-equitable environment, where the Kapakkuna were both women and men. 
Cápac Raymi is when the fields are prepared for the sowing of the corn; this is why it is of such great importance for the agricultural villages of Ecuador. Former celebrations of Cápac Raymi saw the realization of the Warachikuy, an initiation ceremony for young men, in which priests would offer animal sacrifices and carry out different trials.

Nowadays, this millenary tradition is being forgotten or ignored by the youth, which is why the authorities decided to restore it and revive the customs and traditions that are being lost due to lack of knowledge. The most important part of this feast is the ritual bath that is performed in order to renew the energies and to ward off all evil. Another ritual performed during the Cápac Raymi ceremony is the giving of the kamari, a working tool that serves as a link between men and Pachamama (Mother Earth). The kamari is given to women and men that are leaders or wise men of their native community; it is a great privilege to receive such a gift. This ritual has endured the passing of the centuries and is still current in Ecuadorian culture and identity. It is a genuine and primordial element of the natives' culture.

\section{Indigenous feasts and traditions in multicultural classrooms}

According to data published by the Spanish Statistical Office, in 2017 there are 141,582 Ecuadorian citizens in Spain, and we must take into account the fact that immigrants register their school-age children in the Spanish national educational system. Given the social-demographic reality of the Ecuadorian population of Spain, the question we must ask ourselves is, "How do we integrate the Ecuadorian cultural heritage consisting of native feasts and traditions of great impact in the curriculum and adapt it to the readily available content, easily taught in class?" School is the institution that must absolutely preserve the cultural identity of Ecuadorian pupils, and it may do so through feasts, folk tales, music and other specific cultural elements. Folk literature is an important tool that contributes to the literary formation and personal evolution of pupils, a means to promote multicultural competency in the classroom. It is thus necessary to link it to popular feasts and traditions.

Languages make up the fabric of our lives and, as elements of cultural practice, are learned through use. Idioms, understood as social languages (Gee 1999), serve as bridges towards our individual development and in forming of our identities. From a Vygotskian perspective, learning occurs while we interact with other people. This way, communication and linguistics are highly important in the learning process; quality education generates meaningful interactions that are beneficial to learning. The appropriation of minority languages, along with the feasts and traditions of Ecuadorian pupils, serves as an instrument in the management of social relations between indigenous pupils and students of other nationalities (all pertaining to the Spanish educational system), as well as in the management of the relations established with teachers - contributing to the creation of communicative scenarios appropriate for a sociocultural practice characterised by the involvement and active participation of children in the practice of knowledge acquisition. 
In what concerns the Valencian community within the framework of multicultural bilingual pedagogy, there is currently a growing interest in the process of teaching two languages in contact and elaborating appropriate methodology oriented towards bilingual pupils. All of this is manifested in a tendency towards the reappraisal and conservation of Valencian language and, on the other hand, in extending the same protectionist treatment towards most of the significant native languages in Latin America as key components of ancient cultures.

Some of the measures that schools could adopt regarding language diversity aspects, in relation to cultural and thematic issues such as the feasts and traditions of the Ecuadorian pupils, are:

- Celebrating one of the significant native feasts;

- Including specific native content in some of the courses;

- Hanging posters with words written in Quichua and other indigenous languages (mainly content with which pupils are familiar);

- Promoting the presence and recognition in the classroom of familiar, indigenous languages and feasts that are specific to Ecuadorian pupils; facilitating pupils' access to them and encouraging their perpetuation, enrichment and development. An important aspect that need not be forgotten is promoting and fostering a positive attitude towards the feasts, traditions and languages of the rest of the pupils as well;

- Collaborating on a permanent basis with the families of Ecuadorian pupils, in order to better organize the feasts in class.

Celebrating indigenous feasts and traditions in a multicultural classroom is a life-forming reality that becomes a part of pupils' identity. One of the basic pillars of modern-day teaching is the transmission of folk values and culture in the process of handing down the knowledge generated by our ancestors to future generations.

\section{Conclusions}

Since the 16th century, American Spanish has been in contact with hundreds of indigenous languages, mutually influencing each other. In what concerns indigenous feasts and traditions, it is worth mentioning that many of them are not totally pure, given the tremendous influence Spanish people have had on them; in time, they adapted, suffered alterations and changed into representations of Catholicism. All traditions were submitted to a range of transformations, causing the authentic element in them, their purity, to alter beyond recognition. Nevertheless, all of mankind's history is a mixture of syncretism, acculturation, encounters among different elements pertaining to various languages and cultures.

In retrospect, the aim of this article was to present an analysis of the main indigenous feasts and traditions of Ecuador that have been preserved to this day and are still celebrated in Andean villages. The feasts that we have presented are: Pawkar Raymi (equinox), the blossoming; Inti Raymi (solstice), harvest time; Coya Raymi (equinox), fertility; and Cápac Raymi (solstice), germination feast. The celebration of the four great Andean feasts that have been preserved to this day is in fact the celebration 
of certain rituals and festivities related to the agricultural cycle, Mother Earth's fertility and cosmic or terrestrial deities. Even though the most important ones are Pawkar and Inti Raymi (being related to harvest), the remaining feasts are also preserved within indigenous communities despite the interdictions imposed by the Catholic faith after the conquest. Maintaining native customs and traditions is a great achievement, especially since they are preserved among the new generations that refuse to let them fall into oblivion. Through these ancestral feasts, the native communities have recovered the traits and values they had prior to the arrival of the Spanish conquerors, whose only interest was in imposing new traditions.

The objective of the current article was to describe the anthroponymy of Ecuadorian deities, their original meaning and, at the same time, to propose a set of measures schools could adopt in order to foster respect and recognition towards the celebration of native feasts that constitute a heritage for the Ecuadorian pupils enrolled in the Spanish educational system.

After all, we must not forget that the preservation of a language is closely tied to the conservation and promotion of a country's feasts and holidays. Culture-specific feasts are characterised by a recreational, diverse and experiential trait (Colomer 1987). We are of the opinion that the loss of the aforementioned feasts within the context of the Spanish school system, especially in relation to the indigenous feasts of the Ecuadorian pupils, is a subject worthy of a more detailed study. In these conditions, schools should select some of the most important feasts pertaining to the indigenous pupils' heritage and incorporate them into the curriculum in order to foster values such as identity and multiculturality in the classroom. Thus, by maintaining an open mind, by being flexible and tolerant towards pupils' native traditions, schools could view diversity as a positive trait, as a source for personal and collective growth, highlighting the elements that the Ecuadorian culture has in common with other cultures and nationalities.

\section{Acknowledgments}

This work was possible with the financial support of the Lifelong Learning Service and Educational Innovation SFPIE (University of Valencia) under the project number UV-SFPIE_RMD16-417099 with the title Preservation of minority languages: Valencian (Spain), Náhuatl (México) and Quichua (Ecuador) in communities with bilingual students.

\section{References}

Chireac, S-M. \& N. Francis. 2016. Las transferencias e interacciones entre el español y las lenguas indígenas americanas. Estudios de Lingüística del Español 37: 45-70.

Colomer, J. 1987. Fiesta y escuela. Recursos para las fiestas populares. Barcelona: Graó.

Eeckhout, P. 2004. Reyes del sol y señores de la luna: inkas e ychsmas en Pachacámac. Chungará (Arica) 36 (2): 495-503.

Gee, J. P. 1999. Discourse Analysis. Theory and Method. London: Routledge. 
Gómez Rendón, J. 2008. Mestizaje lingüístico en los Andes: génesis y estructura de una lengua. Quito: Abya-Yala.

Martín-Gutiérrez, I., D. Díaz Arcos, D. Allen-Perkins \& M. Hinojosa Becerra. 2016. El Pawkar Raymi, la celebración del nuevo tiempo. Cannabis Magazine 143: 88-93.

Martín-Gutiérrez, I., D. Díaz Arcos, D. Allen-Perkins \& M. Hinojosa Becerra. 2016. Inti Raymi. La fiesta del Sol. Cannabis Magazine 145: 96-103.

Montemayor, C. 2007. Diccionario del náhuatl en el español de México. México DF: Universidad Nacional Autónoma de México.

National Statistics and Census Institute of Ecuador. 2010. http://www.ecuadorencifras.gob.ec/ institucional/home/ (accessed July 5, 2017).

Ortega Haboud, S. 2008. Patrimonio lingüístico, revitalización y documentación de lenguas amenazadas. https://www.researchgate.net/profile/Jorge_Gomez_Rendon/publication/254919413_Patrimonio linguistico_revitalizacion_y_documentacion_de_lenguas amenazadas/links/548ef73b0cf2d1800d861 cbb/Patrimonio-lingueistico-revitalizacion-ydocumentacion-de-lenguas-amenazadas.pdf (accessed July 7, 2017).

Spanish Statistical Office 2017. http://www.ine.es/ (accessed July 5, 2017). 